\title{
EFEKTIVITAS SIRIP PEREDAM DALAM MEREDAM EFEK FREE SURFACE YANG MEMPENGARUHI GERAKAN ROLLING KAPAL MODEL
}

\section{THE EFFECTIVENESS OF ABSORBERS FINS IN REDUCING FREE SURFACE EFFECT THAT AFFECTS ROLLING MOTION OF SHIP MODEL}

Dwi Putra Yuwandana1, Yopi Novita², Budhi Hascaryo Iskandar ${ }^{2}$

${ }^{1}$ Program Studi Teknologi Perikanan Laut, Sekolah Pascasarjana

${ }^{2}$ Departemen Pemanfaatan Sumberdaya Perikanan

Fakultas Perikanan dan Ilmu Kelautan, Institut Pertanian Bogor

E-mail: dwiputrayuwandana@gmail.com

\begin{abstract}
Ships carrying liquid cargo will experience free surface effects. It is a free movement of liquid cargo in the hold, especially during rolling motions. The use of absorber fins in hold is an alternative to reduce the free surface effect. This study aimed to determine the minimum size of absorber fins that were still effective to reduce the effect of free surface affecting the rolling motion of ship. The experimental method was applied by using a model ship with hold. Four size of absorber fins were used as treatments in this experiment. Data were analyzed by comparative numerical and statistical tests using a completely randomized design. During the experimental, four variable that were observed such as angle of rolling ship model, rolling duration, rolling frequency and rolling period. The result showed that the use of absorber fins with the size of $(10 \%)$ of the free surface area was effective to reduce the free surface effect toward the rolling motion of ship models.
\end{abstract}

Keywords: absorber fins, effectivity, free surface, rolling motion

\begin{abstract}
ABSTRAK
Kapal yang mengangkut muatan cair akan menimbulkan free surface. Free surface tersebut merupakan pergerakan bebas muatan cair pada palka terutama saat terjadi gerakan rolling. Efek free surface dapat mempengaruhi gerakan rolling yang terjadi. Penggunaan sirip peredam pada palka merupakan salah satu alternatif cara untuk meredam efek free surface yang terjadi pada kapal bermuatan cair. Penelitian ini bertujuan untuk menentukan luasan minimal sirip peredam yang masih efektif untuk meredam efek free surface yang mempengaruhi gerakan rolling kapal. Metode penelitian yang dilakukan adalah metode eksperimen menggunakan kapal model dan palka model dengan 4 perlakuan luasan sirip peredam. Analisis data dilakukan dengan cara komparatif numerik dan uji statistik menggunakan rancangan acak lengkap. Kajian dilakukan terhadap sudut kemiringan rolling kapal model, rolling duration, rolling period dan frekuensi rolling. Berdasarkan hasil kajian penggunaan sirip peredam $(10 \%)$ dari luas free surface cukup efektif untuk meredam efek free surface yang mempengaruhi gerakan rolling kapal model.
\end{abstract}

Kata kunci: efektivitas, free surface, rolling, sirip peredam 


\section{PENDAHULUAN}

Kapal pengangkut ikan hidup (KPIH) merupakan kapal yang digunakan untuk mengangkut benih-benih ikan atau pun sumberdaya ikan dalam keadaan hidup. KPIH merupakan jenis kapal yang muatannya sebagaian besar adalah muatan cair. Muatan cair pada pengangkutan ikan hidup biasanya tidak memenuhi palka secara keseluruhan sehingga menimbulkan permukaan bebas (free surface) pada muatan cair tersebut. Permukaan bebas tersebut mengakibatkan muatan cair dalam palka bergerak bebas terutama saat melakukan gerakan rolling. Hal ini terjadi dikarenakan sifat zat cair yang akan selalu bergerak mengikuti perubahan bentuk wadahnya dan mengakibatkan titik beratnya pun bergeser.

Free surface merupakan permukaan bebas yang biasanya ada pada benda berbentuk cair yang mengakibatkan benda cair tersebut berubah bentuk sesuai dengan media yang ditempatinya (Lewis 1988). Efek free surface pada kapal bermuatan cair sangat berpengaruh terhadap stabilitas kapal tersebut. Stabilitas kapal bermuatan cair memiliki stabilitas yang lebih buruk akibat pergeseran titik berat muatan yang berubah-ubah. Permukaan bebas tersebut mengakibatkan muatan cair dalam palka bergerak bebas terutama saat melakukan gerakan rolling. Gerakan rolling merupakan gerak kapal yang paling mendominasi ketika kapal berinteraksi dengan gelombang. Gerakan rolling merupakan salah satu indikator yang menentukan kualitas stabilitas kapal dan kenyamanan di atas kapal. Efek free surface yang sangat besar selain dapat memperburuk stabilitas kapal dapat mengakibatkan kapal tersebut terbalik/capsize. Penelitian Novita (2011) menyimpulkan bahwa efek free surface dapat menurunkan nilai-nilai parameter stabilitas dan meningkatkan rolling periode yang berdampak pada kemampuan kapal kembali pada posisi semula setelah terjadinya oleng. Kondisi ini didukung oleh penelitian Liliana et al. (2011) yang menyatakan bahwa kapal dengan muatan cair memiliki rolling period lebih besar 0,10 detik dibandingkan dengan kapal dengan muatan padat. Rolling periode kapal yang tinggi apabila berhadapan dengan gelombang-gelombang yang memiliki periode yang cepat dapat meningkatkan risiko kapal (Novita 2011).

Penelitian mengenai upaya dalam meredam efek free surface, berdasarkan hasil penelitian Novita et al. (2012) menyatakan bahwa penggunaan sirip peredam pada bagian dalam palka mampu mengurangi efek free surface pada muatan cair. Hasil penelitian tersebut menyatakan bahwa keberadaan sirip peredam mampu meredam kemiringan dari profil permukaan air pada palka saat diolengkan sebesar 40-60\% dan waktu redam sebesar 33.50-50\%. Penelitian Novita (2012) pula menyatakan bahwa pemasangan sirip peredam yang paling efektif yaitu sejajar dengan free surface. Hasil penelitian tersebut menyatakan posisi sirip peredam yang sejajar dengan free surface dapat mereduksi kemiringan free surface hingga $50 \%$ dan mereduksi waktu redam sebesar $59.70 \%$.

Penelitian ini merupakan penelitian lanjutan dari penelitian sebelumnya mengenai upaya meredam efek free surface pada muatan cair. Penelitian ini akan mengkaji efektivitas luasan sirip peredam terhadap luasan free surface dalam meredam efek free surface pada palka bermuatan cair sehingga stabilitas kapal akan tetap baik. Tujuan dari penelitian ini adalah menentukan luasan minimal sirip peredam yang masih efektif untuk meredam efek free surface yang mempengaruhi gerakan rolling kapal model.

\section{METODE PENELITIAN}

Penelitian ini dilaksanakan pada bulan Oktober-Desember 2015 di Laboratoriun Desain dan Dinamika Kapal Departemen Pemanfaatan Sumberdaya Perikanan, Fakultas Perikanan dan Ilmu Kelautan untuk pembuatan kapal model dan kolam percobaan Departemen Pemanfaatan Sumberdaya Perikanan, Fakultas Perikanan dan Ilmu Kelautan, Institut Pertanian Bogor untuk melakukan uji coba kapal model. Alat dan bahan yang digunakan dalam penelitian ini adalah kapal model (Gambar 1), palka model tanpa sirip peredam dan palka model dengan sirip peredam (Gambar 2) yang digunakan sebagai perlakuan dalam penelitian, timbangan yang digunakan untuk mengukur berat kapal dan muatannya, kamera, alat pendeteksi kemiringan kapal, waterpass sebagai alat untuk memantau kondisi kapal yang seimbang, dan air sebagai muatan yang dimasukkan ke dalam palka model.

Data yang digunakan dalam penelitian ini adalah data primer yang dikumpulkan secara langsung selama eksperimen. Adapun jenis data yang diambil adalah data profil rolling motion diantaranya sudut oleng, 
rolling duration, rolling period dan frekuensi rolling. Pengumpulan data dilakukan menggunakan metode eksperimen dengan 4 perlakuan (Tabel 1). Adapun tahapan pengumpulan data tersaji seperti Gambar 3. Pengolahan data untuk profil rolling motion kapal model seperti, profil rolling, frekuensi rolling dan rolling duration didapatkan dari rekaman data pada alat pendeteksi kemiringan kapal dan rekaman kamera. Data profil rolling setiap perlakuan kemudian dibuat grafik, adapun data frekuensi rolling dan rolling duration ditabulasi untuk dianalisis kemudian. Data rolling period diperoleh dari rolling duration dibagi dengan frekuensi rolling yang terjadi dengan persamaan sebagai berikut:

$$
\mathrm{T}=\frac{R d}{\omega}
$$

keterangan:

$\mathrm{T}=$ Periode rolling rata-rata

$R d=$ Rolling duration

$\omega=$ Frekuensi rolling

Analisis data dilakukan dengan cara komparatif numerik dan uji statistik. Analisis komparatif dilakukan dengan membandingkan profil rolling motion palka tanpa sirip peredam dengan palka yang menggunakan sirip peredam. Uji statistik yang dilakukan menggunakan rancangan acak lengkap (RAL) (Steel \& Torrie 1995), karena hanya menggunakan satu jenis muatan cair dengan beberapa perlakuan luasan sirip peredam pada palka. Uji statistik ini dilakukan untuk mengkaji adanya pengaruh pada perlakuan yang dilakukan yaitu perbedaan luasan sirip peredam yang digunakan. Uji statistik menggunakan RAL dilakukan untuk mengkaji pengaruh setiap perlakuan terhadap faktor-faktor berikut:

1. Rolling period

2. Rolling duration

3. Frekuensi rolling

4. Kemiringan rolling

Model linear percobaan dapat dirumuskan sebagai berikut:

$\mathrm{Yij}=\mu+\tau i+\varepsilon i j$, dimana $\mathrm{i}=1,2, \ldots, \mathrm{t}$ dan $\mathrm{j}$ $=1,2, \ldots, \mathrm{r}$

Keterangan:

Yij = Pengamatan pada perlakuan ke-i ulangan ke-j

$\mu \quad=$ Rataan umum

ti $\quad=$ Pengaruh perlakuan ke-i

cij = Pengaruh acak pada perlakuan ke-i ulangan ke-j

Hipotesis yang digunakan dalam analisis data adalah :

1. $\mathrm{HO}=\mu \mathrm{A}=\mu \mathrm{B}=\mu \mathrm{C}=\mu \mathrm{D}$, maka luasan sirip peredam yang berbeda tidak berpengaruh terhadap profil rolling motion.

2. $\mathrm{HO} \neq \mu \mathrm{A} \neq \mu \mathrm{B} \neq \mu \mathrm{C} \neq \mu \mathrm{D}$, maka luasan sirip peredam yang berbeda berpengaruh terhadap profil rolling motion.

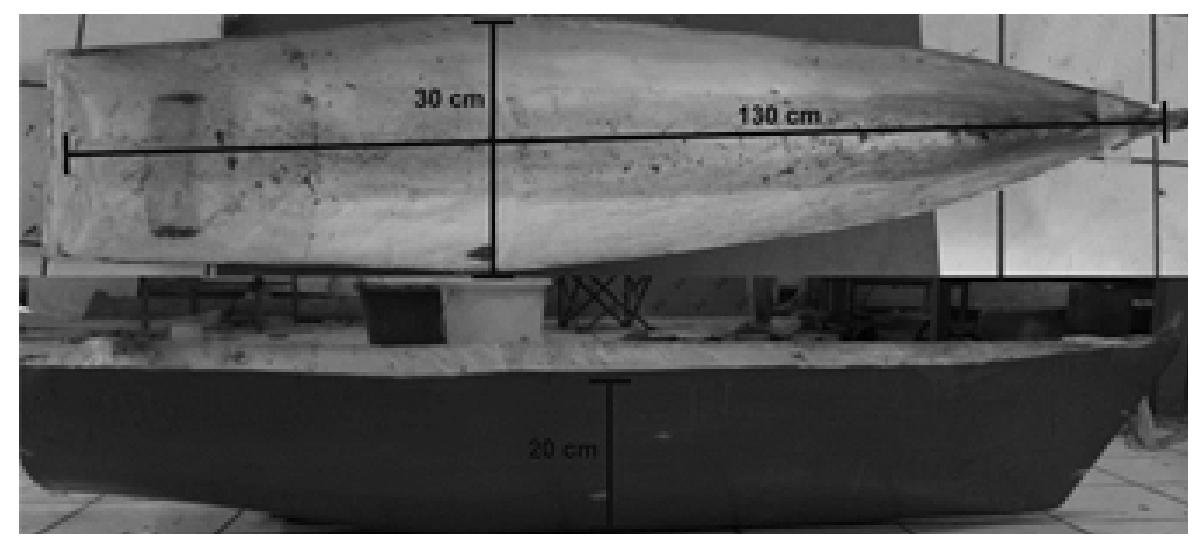

Gambar 1. Kapal model 


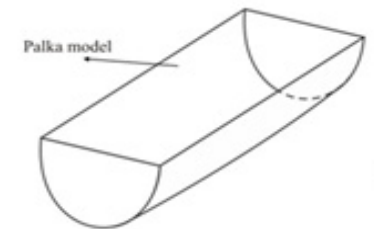

(a) Palka model tanpa sirdam

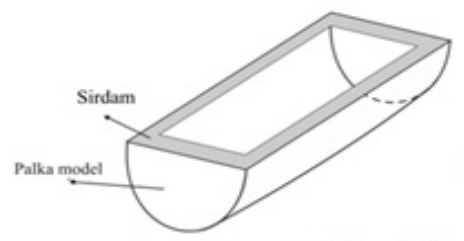

(c) Palka model sirdam $20 \%$ dari luasan free surface

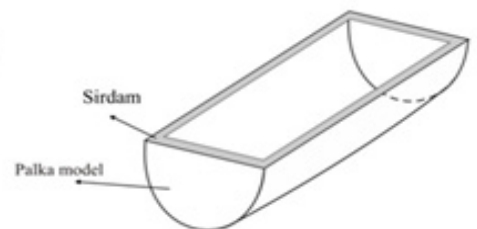

(b) Palka model sirdam $10 \%$ dari luasan free surface

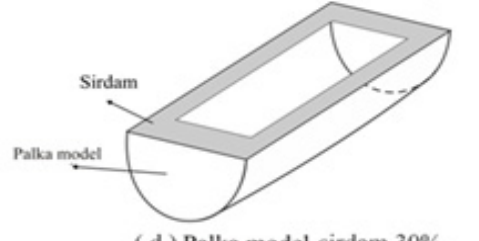

(d) Palka model sirdam $30 \%$ dari luasan free surface

Gambar 2. Palka model

Tabel 1. Perlakuan luasan sirip peredam pada palka model

\begin{tabular}{clc}
\hline Perlakuan & \multicolumn{1}{c}{ Luasan sirip peredam pada model palka } & Kode perlakuan \\
\hline 1 & $\begin{array}{l}\text { Model palka tanpa sirip peredam } \\
\text { Model palka dengan luasan sirip peredam (10\%) } \\
\text { dari luasan free surface }\end{array}$ & P2 \\
3 & $\begin{array}{l}\text { Model palka dengan luasan sirip peredam (20\%) } \\
\text { dari luasan free surface }\end{array}$ & P3 \\
4 & $\begin{array}{l}\text { Model palka dengan luasan sirip peredam (30\%) } \\
\text { dari luasan free surface }\end{array}$ & P4 \\
\hline
\end{tabular}

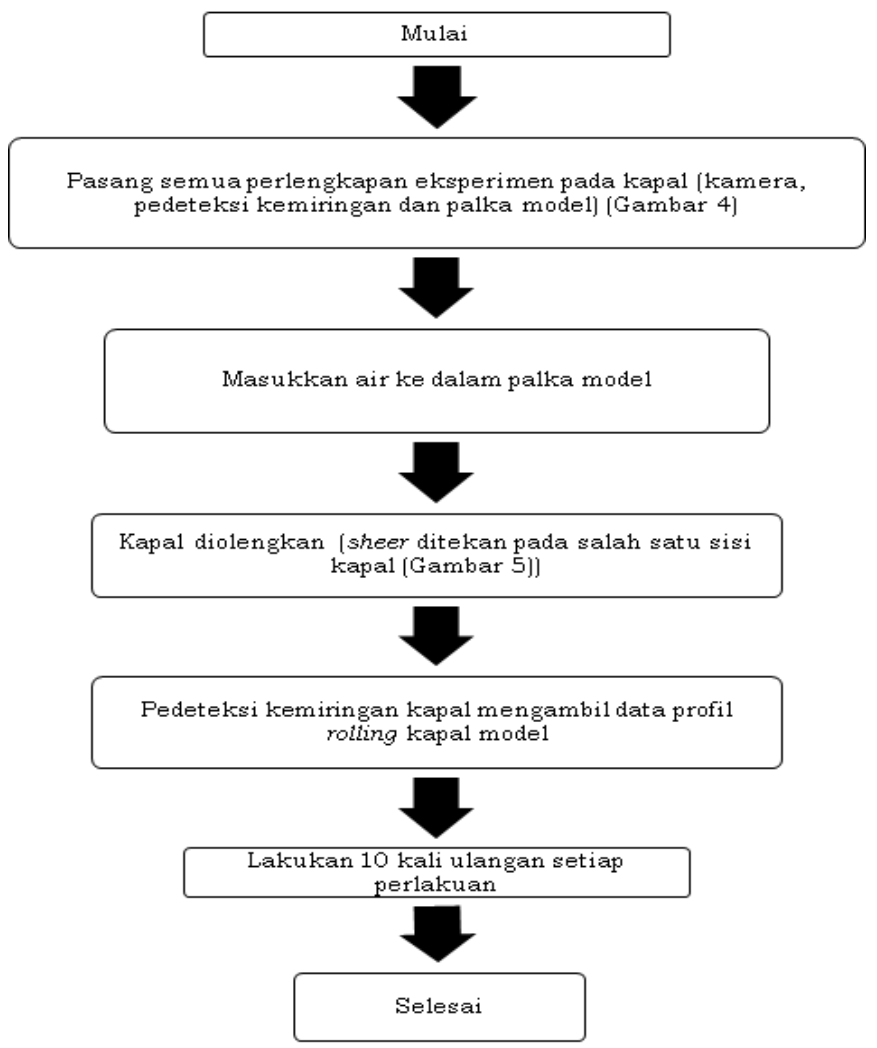

Gambar 3. Diagram alir pengumpulan data 


\section{HASIL DAN PEMBAHASAN}

Sebelum melakukan eksperimen pengambilan data dilakukan dengan mengukur berat kapal model dan palka model serta muatannya yang digunakan dalam penelitian ini. Berdasarkan hasil penimbangan kapal berat kapal model beserta palka tanpa muatan adalah 6.95 g, sedangkan berat kapal yang telah diisi muatan cair yaitu sebesar 18.29 g. Panjang pada garis air (Length of Waterline (LWL)) dan tinggi sarat air (d) ketika kapal model tanpa muatan yaitu $115 \mathrm{~cm}$ dan $8 \mathrm{~cm}$, sedangkan panjang pada garis air (LWL) dan tinggi sarat air ketika kapal model berisi muatan yaitu $123 \mathrm{~cm}$ dan $14 \mathrm{~cm}$.

Titik berat kapal model secara longitudinal (LCG) dan titik berat kapal model secara vertikal (KG) pada kapal model tanpa muatan yaitu $-7.50 \mathrm{~cm}$ dan $8 \mathrm{~cm}$, sedangkan titik berat kapal model secara longitudinal (LCG) dan titik berat kapal model secara vertical (KG) pada kapal model dengan muatan yaitu $-8.43 \mathrm{~cm}$ dan $6.45 \mathrm{~cm}$. Nilai negatif pada nilai LCG berarti titik berat kapal model berada di belakang midship kapal model. Nilai KG diukur dari badan kapal model bagian bawah sampai titik gravitasi $(G)$. Kajian terhadap efektivitas penggunaan sirip peredam dalam meredam efek free surface terhadap gerakan rolling kapal model, dilakukan kajian terhadap sudut kemiringan kapal model, rolling duration, rolling period dan frekuensi rolling.

\section{Sudut kemiringan data model}

Sudut kemiringan kapal model adalah sudut yang terbentuk dari kemiringan kapal model saat terjadi gerakan rolling terhadap posisi kapal model dalam keadaan tegak. Gambar 6 menyajikan perubahan sudut kemiringan dan lama waktu rolling yang terjadi pada kapal model ketika melakukan gerakan rolling pada setiap perlakuan.

Kapal model dengan palka tanpa sirip peredam (P1) mengalami gerakan rolling dengan sudut kemiringan yang paling besar jika dibandingkan dengan perlakuan lainnya, yaitu sebesar $14.34^{\circ}$. Sedangkan perlakuan palka yang menggunakan sirip peredam sudut kemiringannya lebih kecil dibandingkan dengan perlakuan palka tanpa sirip peredam. Perlakuan P2 memiliki sudut kemiringan sebesar $9.43^{\circ}$ dan perlakuan P3 memiliki sudut kemiringan sebesar $7.05^{\circ}$, sedangkan perlakuan palka dengan sirip peredam yang memiliki sudut kemiringan yang paling kecil adalah perlakuan P4 yaitu sebesar $5.09^{\circ}$. Berdasarkan hasil penelitian penggunaan sirip peredam pada palka muatan cair cukup efektif dalam mengurangi sudut kemiringan kapal saat rolling. Palka dengan sirip peredam 10\% (P2) dapat menurunkan sudut kemiringan kapal model sebesar $34.20 \%$ dibandingkan palka tanpa sirip peredam, palka dengan sirip peredam 20\% (P3) dapat menurunkan sudut kemiringan kapal model sebesar 50.8\% dibandingkan palka tanpa sirip peredam, dan palka dengan sirip peredam 30\% (P4) data menurunkan sudut kemiringan kapal model saat oleng sebesar $64.50 \%$ dibandingkan palka tanpa sirip peredam.

\section{Rolling duration (waktu redam) kapal model}

Rolling duration merupakan lamanya waktu yang dibutuhkan oleh model kapal untuk melakukan gerakan rolling dari awal terjadinya oleng hingga kapal model berhenti oleng atau tegak kembali. Gambar 7 disajikan perbandingan rolling duration yang terjadi pada keempat perlakuan yang dilakukan.

Kapal model dengan palka tanpa sirip peredam $(\mathrm{P} 1)$ memiliki rolling duration yang paling tinggi yaitu rata-rata 25.843 detik. Adapun untuk Perlakuan P2 memiliki rolling duration rata-rata sebesar 8.767 detik, perlakuan P3 memiliki rolling duration ratarata sebesar 5.571 detik dan perlakuan P4 memiliki rolling duration yang paling kecil yaitu rata-rata sebesar 4.814 detik.

Melihat data hasil percobaan yang dilakukan penggunaan sirip peredam dapat menurunkan waktu rolling duration kapal model yang mengangkut muatan cair. Perlakuan penggunaan sirip peredam $10 \%$ dari luas free surface (P2) pada palka dapat menurunkan rolling duration sebesar 66\% dari perlakuan palka tanpa sirip peredam, perlakuan penggunaan sirip peredam $20 \%$ dari luas free surface (P3) pada palka dapat menurunkan rolling duration sebesar $78.40 \%$ dari perlakuan palka tanpa sirip peredam, sedangkan perlakuan penggunaan sirip peredam (30\%) dari luas free surface $(\mathrm{P} 4)$ pada palka dapat menurunkan rolling duration yang paling besar yaitu sebesar $(81.40 \%)$ dari perlakuan palka tanpa sirip peredam. Berdasarkan uji statistik terhadap rolling duration antara P1 vs P2 menunjukkan bahwa nilai $F_{\text {hit }}>F_{\text {tab }}$ atau nilai $\mathrm{P}$-Value $<0.05$. Begitu juga hasil uji statistik antara P1 vs P3 dan P1 vs P4 
menunjukkan bahwa nilai ${ }_{\text {Fhit }}>\mathrm{F}_{\text {tab }}$ atau nilai $\mathrm{P}$-Value $<0.05$. Kondisi ini menunjukkan bahwa terdapat perbedaan rolling duration antara palka tanpa sirip peredam dengan palka yang menggunakan sirip peredam. Hal ini berarti penggunaan sirip peredam pada palka bermuatan cair memberikan pengaruh yang nyata terhadap perbedaan rolling duration.

\section{Rolling period kapal model}

Bhattacharyya (1978) mendefinisikan rolling period adalah waktu yang dibutuhkan oleh kapal saat melakukan gerakan rolling untuk kembali pada kemiringan awalnya atau bias dikatakan waktu yang dibutuhkan kapal untuk melakukan 1 gerakan rolling. Gambar 8 menyajikan nilai rata-rata rolling period kapal model pada keempat perlakuan.

Kapal model dengan perlakuan palka tanpa sirip peredam (P1) memiliki rolling period yang paling tinggi yaitu rata-rata 2.12 detik. Adapun untuk perlakuan P2 memiliki rolling period rata-rata sebesar 1.48 detik, perlakuan P3 memiliki rolling period rata-rata sebesar 1.48 detik dan perlakuan P4 memiliki rolling period yang paling kecil yaitu rata-rata sebesar 1.28 detik. Berdasarkan data hasil percobaan yang dilakukan, penggunaan sirip peredam dapat menurunkan rolling period kapal model yang mengangkut muatan cair. Perlakuan penggunaan sirip peredam 10\% dari luas free surface (P2) pada palka dapat menurunkan rolling period sebesar $30 \%$ ) dari perlakuan palka tanpa sirip peredam, perlakuan penggunaan sirip peredam 20\% dari luas free surface (P3) pada palka dapat menurunkan rolling period sebesar $30.40 \%$ dari perlakuan palka tanpa sirip peredam, sedangkan perlakuan penggunaan sirip peredam 30\% dari luas free surface (P4) pada palka dapat menurunkan rolling period yang paling besar yaitu sebesar 39.90\% dari perlakuan palka tanpa sirip peredam. Berdasarkan uji statistik terhadap rolling period antara $\mathrm{P} 1$ vs $\mathrm{P} 2$ menunjukkan bahwa nilai $\mathrm{F}_{\text {hit }}>\mathrm{F}_{\text {tab }}$ atau nilai $\mathrm{P}$-Value $<0.05$, begitu juga hasil uji statistik antara $\mathrm{P} 1$ vs $\mathrm{P} 3$ dan P1 vs P4 menunjukkan bahwa nilai $F_{\text {hit }}$ $>\mathrm{F}_{\text {tab }}$ atau nilai P-Value $<0.05$. Kondisi ini menunjukkan bahwa terdapat perbedaan rolling period antara palka tanpa sirip peredam dengan palka yang menggunakan sirip peredam. Hal ini berarti penggunaan sirip peredam pada palka bermuatan cair memberikan pengaruh yang nyata terhadap perbedaan rolling period.

\section{Frekuensi rolling kapal model}

Frekuensi rolling menurut Bhattacharyya (1978) merupakan banyaknya gerakan oleng kapal dalam satu satuan waktu tertentu. Gambar 9 Menyajikan ratarata frekuensi rolling kapal model yang terjadi pada keempat perlakuan.

Frekuensi rolling pada perlakuan P1 hingga perlakuan P4 semakin besar. Perlakuan P1 memiliki frekuensi rolling yang paling rendah yaitu rata-rata 0.47 kali dalam 1 detik. Adapun frekuensi rolling untuk perlakuan $\mathrm{P} 2$ yaitu ratarata 0.68 kali dalam 1 detik, perlakuan $\mathrm{P} 3$ memiliki frekuensi rolling rata-rata $0.68 \mathrm{kali}$ dalam 1 detik dan perlakuan P4 memiliki frekuensi rolling yaitu rata-rata 0.79 kali dalam 1 detik. Berdasarkan uji statistik terhadap frekuensi rolling antara P1 vs P2 menunjukkan bahwa nilai $\mathrm{F}_{\text {hit }}>\mathrm{F}_{\text {tab }}$ atau nilai $\mathrm{P}-$ Value $<0.05$, begitu juga hasil uji statistik antara P1 vs P3 dan P1 vs P4 menunjukkan bahwa nilai Fhit $>$ Ftab atau nilai $\mathrm{P}-$ Value < 0.05. Hal ini menunjukkan bahwa terdapat perbedaan frekuensi rolling antara palka tanpa sirip peredam dengan palka yang menggunakan sirip peredam. Kondisi tersebut menunjukkan penggunaan sirip peredam pada palka bermuatan cair memberikan pengaruh yang nyata terhadap perbedaan frekuensi rolling.

Tabel 2 menyajikan rekapitulasi data hasil pengamatan yang dibandingkan hasil analisis yang dilakukan.

\section{Pembahasan}

Sudut kemiringan oleng kapal semakin mengecil seiring bertambahnya waktu, dikarenakan ada daya redam pada gerakan rolling. Daya redam tersebut terjadi disebabkan berkurangnya energi gerakan rolling akibat terserap oleh resistensi air (Bhattacharyya 1978). Selain itu, penggunaan sirip peredam pada palka juga dapat menurunkan sudut kemiringan oleng kapal model. Penggunaan sirip peredam dapat memperkecil efek free surface pada palka. Dimana efek free surface yang terjadi pada palka bermuatan cair, yaitu adanya pergerakan massa air ketika kapal oleng mempengaruhi sudut kemiringan kapal model. Efek free surface tersebut dapat mengakibatkan adanya sloshing. Menurut Lee et al. (2005) sloshing adalah pergerakan massa air (free surface) yang membentur dinding palka ketika kapal oleng. Adanya massa air yang bergerak tersebut 
mengakibatkan adanya energi atau tekanan tambahan yang dapat menambah keolengan kapaldan menahangerakanolengbalikkapal. Faltinsen \& Rognebakke (2000) menyatakan bahwa gerakan muatan cair dalam tangki atau palka sangat mempengaruhi olah gerak kapal khususnya gerakan rolling. Selanjutnya oleh Rognebakke \& Faltinsen (2003) menyatakan bahwa gerakan kapal ditambah dengan adanya sloshing dapat menyebabkan gerakan kapal yang semakin besar. Hal tersebut sesuai dengan hasil penelitian, dimana sudut kemiringan kapal model dengan muatan cair pada perlakuan palka tanpa sirip peredam lebih besar dibandingkan dengan perlakuan palka yang menggunakan sirip peredam. Berkurangnya sudut kemiringan oleng kapal model pada palka dengan sirip peredam dikarenakan free surface pada muatan cair yang ada di palka ketika terjadi gerakan rolling tertahan oleh sirip peredam yang terpasang di dalam palka. Hal ini juga sesuai dengan penelitian Novita et al. (2012) yang menyatakan bahwa penggunaan sirip peredam pada palka muatan cair dapat menurunkan efek free surface yang terjadi pada palka bermuatan cair. Sehingga massa air yang membentur dinding kapal model berkurang. Fenomena inilah yang mengakibatkan gerakan rolling kapal model yang dilengkapi dengan sirip peredam di dalam palka lebih kecil jika dibandingkan dengan kapal model yang tidak dilengkapi dengan sirip peredam. Berdasarkan hasil penelitian yang didapat penggunaan sirip peredam pada palka mampu memperkecil sudut kemiringan kapal model saat melakukan gerakan rolling. Rolling duration merupakan lamanya waktu yang dibutuhkan oleh kapal untuk kembali tegak setelah ada gaya yang mengolengkan kapal. Kapal yang memiliki nilai rolling duration yang lebih kecil dapat dikatakan memiliki stabilitas yang lebih baik dibandingkan kapal yang memiliki nilai rolling duration yang besar. Rolling duration dipengaruhi oleh besaran sudut kemiringan oleng yang terjadi pada kapal model. Semakin besar sudut kemiringannya maka nilai rolling durationnya semakin besar, karena sudut oleng yang lebih besar membutuhkan waktu yang lebih lama juga untuk melakukan oleng. Kapal model dengan perlakuan palka tanpa sirip peredam memiliki rolling duration yang lebih besar dibandingkan perlakuan palka dengan sirip peredam. Hal tersebut terjadi selain pengaruh sudut kemiringan oleng yang besar juga dipengaruhi oleh efek free surface yang mengoleng bebas tanpa hambatan sehingga menambah gaya kapal untuk terus melakukan gerakan rolling sehingga rolling durationnya meningkat. Hal ini diduga akibat gerakan free surface meningkatkan damping moment coefficient kapal, sebagaimana yang disampaikan oleh Lee et al. (2005). Dimana damping moment coefficient menurut Bhattacharyya (1978) merupakan koefisien momen yang menunjukkan kemampuan kapal untuk meredam gaya dari luar. Berbeda dengan perlakuan palka dengan sirip peredam efek free surface yang terjadi teredam oleh adanya sirip peredam. Sirip peredam tersebut menghambat gaya tambahan yang dapat timbul akibat efek free surface. Berdasarkan penelitian Novita (2011) sirip peredam dapat menahan aliran free surface yang terjadi pada palka muatan cair, bukan hanya menahan aliran free surface tetapi sirip peredam dapat mengakibatkan adanya refleksi yang ditimbulkan oleh aliran free surface yang menabrak sirip peredam. Refleksi aliran free surface tersebut biasanya memiliki gaya atau tekanan yang sama dengan aliran free surface yang mengenai sirip peredam, namun arahnya berlawanan. Energi tersebutlah yang dapat menghambat gerakan rolling kapal pula sehingga rolling yang terjadi akan lebih cepat teredam dan rolling duration pun akan kecil. Permukaan muatan cair dalam palka yang sangat dinamis dapat membuat kapal lebih sulit untuk kembali tegak setelah ada gaya yang membuat kapal rolling, sehingga rolling duration meningkat. Berdasarkan tiga perlakuan palka yang menggunakan sirip peredam palka dengan sirip peredam 20\% (P3) memiliki selisih antara nilai $\mathrm{F}_{\text {hit }}$ dan $\mathrm{F}_{\text {tab }}$ lebih besar dibandingkan dengan perlakuan palka dengan sirip peredam $10 \% \quad(\mathrm{P} 2)$, namun palka dengan sirip peredam 30\% (P4) memiliki selisih antara nilai $\mathrm{F}_{\text {hit }}$ dan $\mathrm{F}_{\text {tab }}$ paling besar dibandingkan dengan perlakuan lainnya. Kondisi ini menunjukkan semakin luas sirip peredam yang digunakan maka akan semakin efektif untuk mengurangi rolling duration kapal model. Jika mengacu pada definisi rolling duration, maka dapat dikatakan bahwa perlakuan palka dengan sirip peredam $30 \%(\mathrm{P} 4)$ memiliki nilai rolling duration yang paling kecil. Hal tersebut menunjukkan bahwa kapal model dengan perlakuan P4 memiliki stabilitas yang lebih baik dibandingkan dengan perlakuan yang lainnya. Kondisi ini ditunjukkan dengan lebih cepatnya kapal model pada perlakuan palka dengan sirip peredam 30\% (P4) kembali 
pada posisi semula setelah diolengkan.

Menurut Liliana et al. (2012) rolling period yang terjadi sangat dipengaruhi oleh besarnya sudut kemiringan kapal ketika melakukan oleng. Semakin besar sudut kemiringan kapal ketika oleng, maka rolling period yang terjadi juga semakin besar begitu juga sebaliknya. Hal tersebut sesuai dengan hasil penelitian yang didapat, perlakuan palka tanpa sirip peredam memiliki sudut kemiringan oleng kapal yang besar sehingga nilai rolling periodenya pun besar, sedangkan perlakuan palka dengan sirip peredam 30\% memiliki sudut kemiringan paling kecil sehingga nilai rolling periodenya pun paling kecil. Faktor lain yang dapat mempengaruhi besar kecilnya nilai rolling period adalah adanya efek free surface yang terjadi pada palka bermuatan cair. Efek free surface tersebut yang mengakibatkan adanya sloshing. Sloshing yang mana merupakan adanya volume free surface yang menubruk dinding palka memberikan tekanan tambahan pada kapal untuk melakukan oleng serta menahan gaya balik oleng kapal, sehingga meningkatkan nilai rolling period. Penggunaan sirip peredam pada palka muatan cair dapat menurunkan efek free surface yang ada dalam palka bermuatan cair. Sehingga menurunkan besarnya sloshing yang terjadi, maka gaya yang dapat memicu adanya rolling kapal akan berkurang dan pada akhirnya akan menurunkan nilai rolling period. Hal ini dikemukan juga oleh Novita (2011) sirip peredam dapat menahan aliran free surface yang begerak di dalam palka muatan cair, dan pada volume free surface yang tertahan tersebut terjadi refleksi yang memiliki gaya yang sama dengan volume air yang tertahan tetapi arahnya berlawanan, sehingga menurunkan besarnya sloshing yang pada akhirnya akan menurunkan nilai rolling period. Hal ini menunjukkan bahwa penggunaan sirip peredam dalam penelitian ini dapat menurunkan nilai rolling period yang terjadi pada kapal model. Berdasarkan tiga perlakuan palka yang menggunakan sirip peredam, palka dengan sirip peredam $(20 \%)$ (P3) memiliki selisih antara nilai $\mathrm{F}_{\text {hit }}$ dan $\mathrm{F}_{\text {tab }}$ lebih besar dibandingkan dengan perlakuan palka dengan sirip peredam $(10 \%)(\mathrm{P} 2)$, namun palka dengan sirip peredam (30\%) (P4) memiliki selisih antara nilai $F_{\text {hit }}$ dan $F_{\text {tab }}$ paling besar dibandingkan dengan perlakuan lainnya. Kondisi ini menunjukkan semakin luas sirip peredam yang digunakan maka akan semakin efektif untuk mengurangi rolling period kapal model. Nilai rolling period juga dapat menentukan kualitas stabilitas kapal. Menurut FAO (2009) kapal yang memiliki stabilitas yang baik adalah kapal yang memiliki nilai rolling period yang kecil. Mengacu pada pernyataan tersebut maka berdasarkan hasil penelitian dapat dikatakan bahwa perlakuan palka dengan $30 \%$ (P4) memiliki stabilitas yang baik dibandingkan dengan perlakuan yang lain karena miliki nilai rolling period yang paling kecil.

Nilai rolling period yang terjadi mempengaruhi besarnya frekuensi rolling kapal model. Sabagaimana telah dijelaskan sebelumnya bahwa frekuensi rolling menurut Batthacharyya (1978) merupakan banyaknya gerakan rolling kapal dalam satu satuan waktu. Semakin besar nilai rolling period maka akan semakin kecil nilai frekuensi rollingnya karena rolling period yang besar membuat kapal membutuhkan waktu yang lebih lama untuk melakukan 1 kali gerakan oleng sehingga frekuensinya akan lebih kecil. Fenomena ini terjadi pada penelitian yang dilakukan dimana perlakuan palka tanpa sirip peredam memiliki nilai rolling period yang paling besar dibandingkan dengan perlakuan yang lainnya seperti yang dibahas sebelumnya sehingga nilai frekuensi rollingnya paling kecil, sedangkan pada perlakuan palka dengan sirip peredam 30\% memiliki nilai rolling period yang kecil sehingga frekuensi rollingnya besar. Hal ini sesuai dengan hubungan antara frekuensi dengan periode rolling dimana semakin lama periode yang dibutuhkan maka frekuensinya semakin sedikit $(\mathrm{f}=1 / \mathrm{T})$.

Berdasarkan data pada Tabel 2, ranking pertama diberikan pada perlakuan yang dapat kembali pada posisi tegak yang lebih cepat. Oleh karena itu perlakuan palka dengan sirip peredam 30\% mendapatkan ranking pertama karena memiliki nilai sudut oleng, rolling duration dan rolling period yang lebih kecil. Sedangkan ranking pertama nilai frekuensi rolling diberikan pada perlakuan yang memiliki nilai frekuensi yang lebih tinggi. Berdasarkan data diatas juga bahwa perlakuan palka dengan sirip peredam $30 \%$ paling efektif untuk meredam gerakan rolling yang terjadi. Namun, Perlakuan P2 juga masih cukup efektif untuk meredam gerakan rolling yang terjadi, perlakuan ini dapat memperkecil sudut oleng sebesar $30.3 \%$, rolling duration sebesar $66 \%$ dan rolling period $30 \%$ dibandingkan palka tanpa sirdam. 


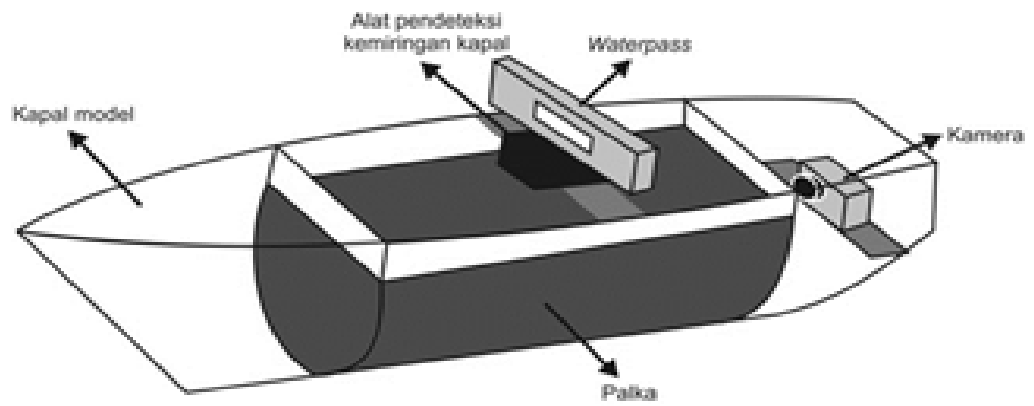

Gambar 4. Ilustrasi pemasangan perlengkapan uji coba

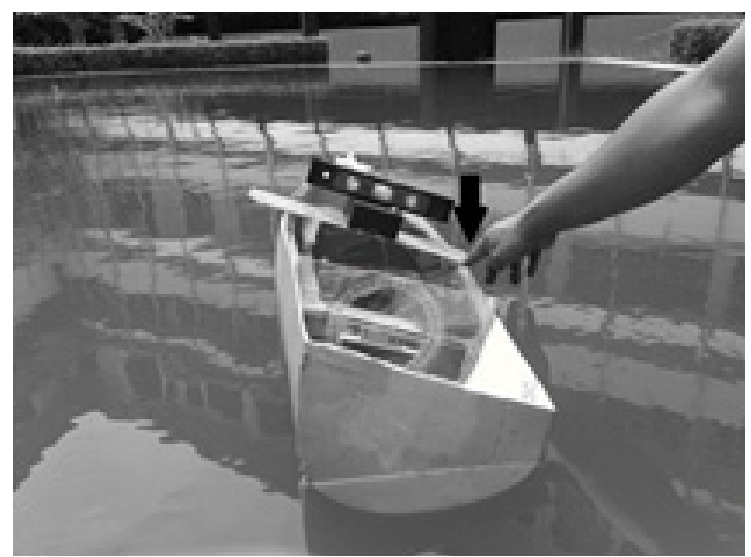

Gambar 5. Penekanan sheer pada salah satu sisi kapal model

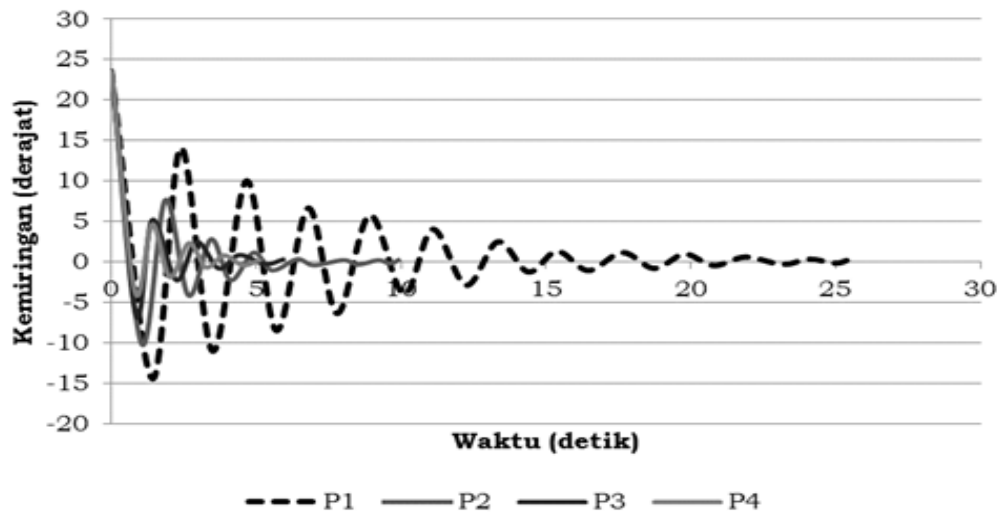

Gambar 6. Profil gerakan rolling 


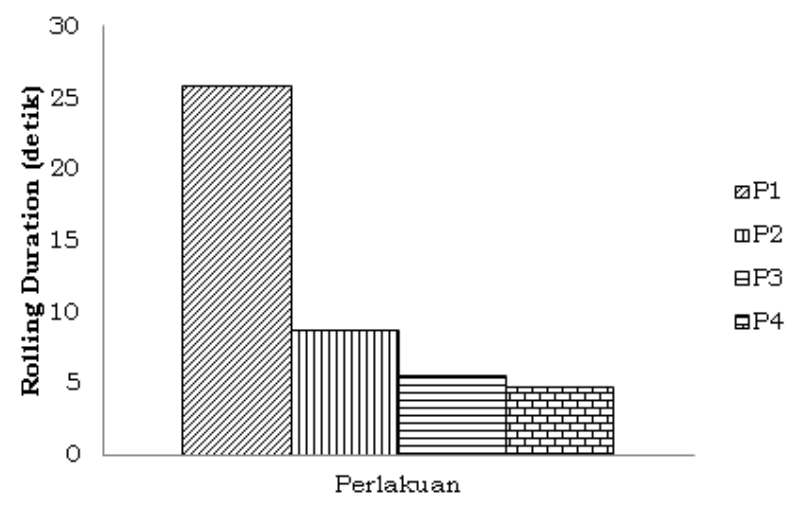

Gambar 7. Rolling duration kapal model

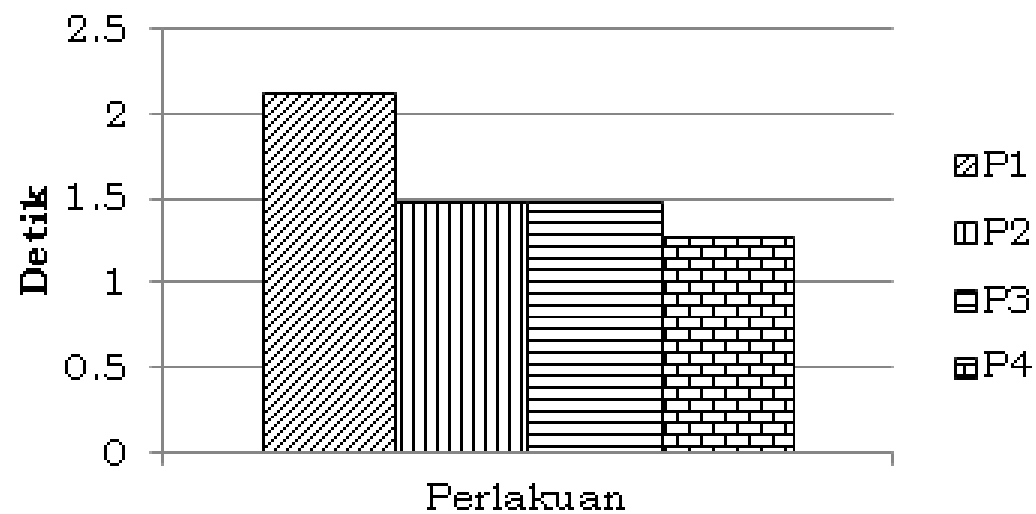

Gambar 8. Rolling period kapal model

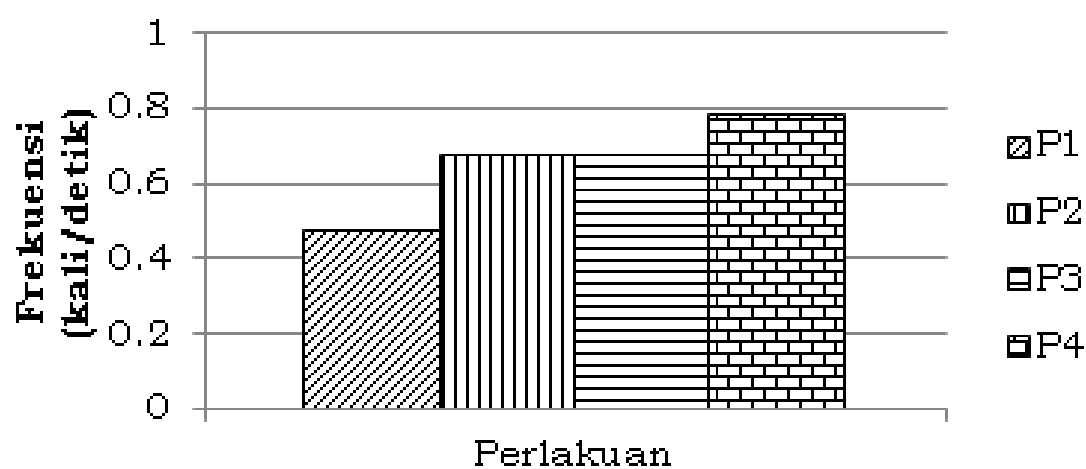

Gambar 9. Frekuensi rolling kapal model dalam waktu 1 detik

Tabel 2. Rekapitulasi data eksperimen hasil anailisis

\begin{tabular}{lcccccccc}
\hline \multirow{2}{*}{\multicolumn{1}{c}{ Parameter }} & \multicolumn{2}{c}{ P1 } & \multicolumn{2}{c}{ P2 } & \multicolumn{2}{c}{ P3 } & \multicolumn{3}{c}{ P4 } \\
\cline { 2 - 9 } & N & R & N & R & N & R & N & R \\
\hline Sudut Oleng (derajat) & 14.34 & IV & 9.43 & III & 7.05 & II & 5.09 & I \\
Rolling Duration (detik) & 25.84 & IV & 8.77 & III & 5.57 & II & 4.81 & I \\
Rolling Period (detik) & 2.12 & IV & 1.48 & III & 1.48 & II & 1.28 & I \\
Frekuensi Rolling (kali /detik) & 0.47 & IV & 0.68 & III & 0.68 & II & 0.79 & I \\
\hline
\end{tabular}




\section{KESIMPULAN DAN SARAN}

\section{Kesimpulan}

Penggunaan sirip peredam dengan luasan $10 \%$ dari luas free surface masih cukup efektif untuk meredam efek free surface yang mempengaruhi gerakan rolling kapal dengan memperkecil sudut oleng sebesar $34.2 \%$, rolling duration sebesar $66 \%$ dan rolling period $30 \%$ dibandingkan palka tanpa sirdam.

\section{Saran}

Perlu diminimalkan pengaruh eksternal pada saat pengujian terhadap olah gerak kapal statis, serta perlu dilakukan penelitian lanjutan mengenai penggunaan sirip peredam dalam mereduksi gerakan rolling pada kondisi perairan yang bergelombang.

\section{DAFTAR PUSTAKA}

Bhattacharyya R. 1978. Dynamics of Marine Vehicles. New York: John Wiley \& Sons, Inc.

Faltinsen OM, Rognebakke OF. 2000. Sloshing in Rectangular Tanks and Interaction with Ships Motions Sloshing. Department of Marine Hydrodynamic. Trondheim, Norway: Norwegian University of Science and Technology

FAO. 2009. Safety practices related to small fishing vessel stability. Rome: FAO.

Lee SK, Surenndran S, Lee G. 2005. Roll performance of small fishing vessel with live fish tank. Ocean Engineering. 32:1873-1885.
Lewis EV. 1988. Principles of Naval Architecture. $2^{\text {nd }}$ Revision, Volume I Stability and Strength. Jersey City, New York: The Society of Naval Architects and Marine Engineers.

Liliana N, Novita Y, Purwangka F. 2012. Rolling period kapal bermuatan padat dan cair serta kaitannya dengan efek free surface. Buletin PSP. 20(3):34- 42.

Novita Y. 2012. Posisi sirip peredam vs ketinggian permukaan air dalam meredam free surface muatan cair di dalam tangki dalam: Isnansetyo A et al. (ed). Seminar Nasional Tahunan IX Hasil Penelitian Perikanan dan Kelautan; 2012 Juni 4; Yogyakarta, Indonesia. Yogyakarta: Universitas Gadjah Mada.

Novita Y. 2011. Pengaruh free surface terhadap stabilitas kapal pengangkut ikan hidup. Buletin PSP. 19(2):34-43.

Novita Y. 2011. Desain palka kapal pengangkut ikan ditinjau dari aspek teknis, mitigasi resiko dan ketahanan hidup ikan [Disertasi]. Bogor: Institut Pertanian Bogor.

Novita Y, Iskandar BH, Murdiyanto B, Wiryawan B. 2012. Pengaruh pemasangan sirdam terhadap free surface muatan cair pada model palka kapal pengangkut ikan hidup. Jurnal Penelitian Perikanan Indonesia. 18(1): 61-68.

Rognebakke OF, Faltinsen OM. 2003. Coupling of Sloshing and Ships Motions. Journal of Ship Reasearch. 47 (3):208-221.

Steel RGD, James HT. Prinsip dan Statistika Suatu Pendekatan Biometrik. Jakarta: Gramedia Pustaka Utama. 